\title{
Limitations of on-site dairy farm regulatory debits as milk quality predictors
}

\author{
Darand L. Borneman, ${ }^{*}$ Kyle Stiegert, $†$ and Steve Ingham $\ddagger^{1}$ \\ *Department of Food Science, University of Wisconsin, 1605 Linden Drive, Madison 53706-1565 \\ †Department of Agricultural and Applied Economics, University of Wisconsin, 427 Lorch Street, Madison 53706-1503 \\ ‡Division of Food Safety, Wisconsin Department of Agriculture, Trade, and Consumer Protection, PO Box 8911, Madison 53708-8911
}

\begin{abstract}
In the United States, compliance with grade A raw fluid milk regulatory standards is assessed via laboratory milk quality testing and by on-site inspection of producers (farms). This study evaluated the correlation between on-site survey debits being marked and somatic cell count (SCC) or standard plate count (SPC) laboratory results for 1,301 Wisconsin grade A dairy farms in 2012. Debits recorded on the survey form were tested as predictors of laboratory results utilizing ordinary least squares regression to determine if results of the current method for on-site evaluation of grade A dairy farms accurately predict SCC and SPC test results. Such a correlation may indicate that current methods of onsite inspection serve the primary intended purpose of assuring availability of high-quality milk. A model for predicting SCC was estimated using ordinary least squares regression methods. Step-wise selected regressors of grouped debit items were able to predict SCC levels with some degree of accuracy (adjusted $\mathrm{R}^{2}=$ 0.1432). Specific debit items, seasonality, and farm size were the best predictors of SCC levels. The SPC data presented an analytical challenge because over $75 \%$ of the SPC observations were at or below a $25,000 \mathrm{cfu} / \mathrm{mL}$ threshold but were recorded by testing laboratories as at the threshold value. This classic censoring problem necessitated the use of a Tobit regression approach. Even with this approach, prediction of SPC values based on on-site survey criteria was much less successful (adjusted $R^{2}=0.034$ ) and provided little support for the on-site survey system as a way to inform farmers about making improvements that would improve SPC. The lower level of correlation with SPC may indicate that factors affecting SPC are more varied and differ from those affecting SCC. Further, unobserved deficiencies in postmilking handling and storage sanitation could enhance bacterial growth and increase SPC, whereas postmilking sanitation will have no effect on SCC because somatic cells do not reproduce in stored
\end{abstract}

Received August 19, 2014.

Accepted November 25, 2014.

${ }^{1}$ Corresponding author: Steve.Ingham@wisconsin.gov milk. Results suggest that close examination, and perhaps redefinition, of survey debits, along with making the survey coincident with SCC and SPC sampling, could make the on-site survey a better tool for ensuring availability of high-quality milk.

Key words: milk, standard plate count, somatic cell count, milk quality, on-farm regulatory survey

\section{INTRODUCTION}

The regulation of grade A milk produced in the United States is based on requirements set by the US Public Health Service (US PHS)/Food and Drug Administration (FDA). The US PHS/FDA publishes the Grade A Pasteurized Milk Ordinance (PMO) which, as of 2012, had been adopted wholly or in part by 45 US states. Wisconsin regulates milk under rules found in the Wisconsin Administrative Code (ATCP 60, 80, and 82; Wisconsin Administrative Code, 2013), which are as stringent as the PMO. The PMO and Wisconsin rules set maximum levels for SCC and SPC: 750,000 cells per $\mathrm{mL}$, and 100,000 cfu per $\mathrm{mL}$, respectively. Bulk tank measures of SCC are widely considered a strong indicator of both milk quality and udder health (Jayarao and Wolfgang, 2003). SPC is also regarded as a milk quality indicator and is influenced by milking equipment maintenance and sanitation, milk storage temperatures, general herd health, and the cleanliness of the farm (Chambers, 2002).

Each Wisconsin dairy farm is assigned to an individual bulk tank unit (BTU), consisting of one or more farms producing milk for a single processor of raw fluid milk. Evaluation of the BTU is part of the Interstate Milk Shipper Program, which is the collective federalstate program intended to ensure the sanitary quality of milk and milk products shipped interstate. Grade A milk processors in each state that meet the PMO requirements are listed in the Interstate Milk Shipper's Report published by FDA Center for Food Safety and Applied Nutrition, Milk Safety Branch. Each grade A dairy farm is associated with only one firm on the Interstate Milk Shipper's Report at a time.

Individual producers (dairy farm operators) are evaluated by state personnel for compliance with Section 
7 of the PMO (US Department of Health and Human Services, 2011). This evaluation, commonly known as survey, is performed separately from dairy farm inspections regularly done by state personnel, although the latter inspections also at least indirectly determine compliance with PMO standards. After a survey, the producer receives an individual rating. Violations observed during survey are recorded as deductions, or debits, and represent noncompliance with a required PMO element. Debits are assigned a value from 1 to 10 points based on their perceived effect on public health. Producers must score at least $90 \%$ on the individual rating to pass. A failing score could result in the loss of a producer's grade A permit, which can lead to a lower price received for milk they produce. Egregious or systemic violations can result in a producer losing the ability to sell milk altogether.

In Wisconsin, farms in a BTU are selected for an unannounced survey by the state agency responsible for survey - the Wisconsin Department of Agriculture, Trade, and Consumer Protection (WDATCP). Farms are typically surveyed every $2 \mathrm{yr}$, although the frequency may differ based on factors such as the number of farms in the state and BTU, and random selection (US Department of Health and Human Services, 2009).

A survey is done by an FDA-certified milk sanitary rating officer (MSRO), who is a state employee standardized, evaluated, and certified by the US PHS/FDA for evaluating milk producers. An MSRO must not have any other regular regulatory inspection, enforcement, or auditing duties that may conflict or interfere with survey objectivity (US Department of Health and $\mathrm{Hu}-$ man Services, 2009). Assessment of deficiencies during survey is based on the professional judgment and training of the MSRO which alone "must dictate whether an observed deficiency is representative of significant day-to-day sanitary conditions or is an anomaly" (US Department of Health and Human Services, 2009); therefore, some variance between MSRO is possible.

Debits outlined in the PMO are observed deficiencies in hygienic practices or conditions believed to be causally linked with poor milk quality. Objective measures of milk quality include SCC and SPC. Research has not conclusively demonstrated a link between subjective on-site evaluation and either SCC or SPC. Previous work conducted by Peeler et al. (1989) and Ingham et al. (2010) examined the link between on-farm inspection results and various milk quality indicators. Both studies focused strictly on the relationship of the indicators with the overall inspection result, but not individual debits or groups of debits within the inspection. Whereas Hutchison et al. (2005) used linear regression to evaluate the relationship of SPC and other milk quality indicators with observed hygiene-related deficiencies, farmers in their study received prior notice of inspection. The authors also did not use the FDA debits and reporting format, and the SPC results used were obtained according to United Kingdom microbiological assay standards (specifically incubation at $30^{\circ} \mathrm{C}$ for $72 \mathrm{~h}$ ), which differ from US regulatory standards. Elmoslemany et al. (2009) and Kelly et al. (2009) likewise examined observable hygiene characteristics for predicting various milk quality indicators, but did not use US regulatory standards.

To date, no known research has been conducted to determine if a relationship exists between one or more observed regulatory debits in Wisconsin dairy farm surveys and corresponding SCC and SPC milk quality results. Proper identification of shortcomings related to SCC or SPC (via survey debits) and subsequent improvements made by the producer could lead to less bacterial contamination (Pantoja et al., 2009) and perhaps improve dairy farm profitability.

The objective of this study was to evaluate whether the debits composing the regulatory survey of Wisconsin dairy farms accurately predict raw milk quality as reflected in SCC and SPC.

\section{MATERIALS AND METHODS}

The approach taken in this observational study was to (1) obtain survey debit, SCC, and SPC data; (2) evaluate, sort, and transform (if appropriate) the data; and (3) repeatedly develop, test, evaluate, and refine predictive equations for SCC and SPC which contained survey debits and other information as independent variables.

\section{Description of Survey Debit Categories}

The form used in the survey of Wisconsin dairy farms contains 82 elements corresponding to required sanitation elements outlined in the PMO. These elements are elsewhere grouped into 19 debit categories (Table 1). Three additional debit categories are based on regulatory records of laboratory test results. A 5-point debit, SCC, is marked if a producer is in warning status as a result of having official reported monthly SCC counts in excess of 750,000 cells $/ \mathrm{mL}$ in 2 of the last $4 \mathrm{mo}$, including the month in which the producer is being surveyed. This debit is uncommon as it only occurs if the survey is done between 3 and $21 \mathrm{~d}$ after a warning letter has been issued and before the plant receiving the producer's milk has submitted a new, acceptable SCC result. A 10-point debit, bacteria count, is marked if a producer is in warning status as a result of having officially reported SPC counts in excess of 100,000 cfu/ $\mathrm{mL}$ in 2 of the last $4 \mathrm{mo}$, including the month in which 
the producer is being surveyed. For reasons similar to those cited for SCC, this debit is also rare. A 10-point debit noted as drug residue analysis (DRA) is charged as a result of a positive drug residue screening result (for $\beta$-lactams) at the processing plant. This is a very rarely observed debit category, as it only happens when a producer is in warning status for a positive drug residue screening, a new negative DRA-screening result has not been received by the state regulatory agency, and the dairy processing plant continues to receive milk from that producer.

\section{Data}

The data used in this study were supplied solely by WDATCP. The 2012 Wisconsin grade A producer surveys contain the debit information, date of survey, and daily milk production weight for each producer, rounded to the nearest hundred-weight (100 pounds = $45.4 \mathrm{~kg})$. In accordance with state regulations, randomly selected monthly SCC and SPC results, determined in a state-certified testing laboratory, are reported to WDATCP by the buyer/processor of each producer's milk. Each milk sample yielding SCC and SPC results was collected by a state-licensed bulk milk weigher sampler, who refrigerated and delivered it to the testing laboratory at a temperature of 0 to $4^{\circ} \mathrm{C}$. Analyses for SCC and SPC were done using methods for which the FDA has published Series 2400 Laboratory Evaluation forms (US FDA, 2013; SCC: various electronic methods or direct microscopic count; SPC: pour plate, Petrifilm, or plate loop count). In total, 1,707 farms were surveyed in Wisconsin in 2012. Of these farms, about 400 did not produce grade A milk for the entire year because of reasons such as not obtaining a grade A permit until partway through 2012, ceasing milk production (retirement, selling all milk-producing cattle, and so on), shifting to grade B milk production, or the farm acquiring a different license number. Data from these producers were not used, leaving data from 1,301 producers for analysis. A summary of the farm data are shown in Table 2. Mastitis treatment records are not required to be made available to WDATCP under state regulations and thus were not obtained for this study.

\section{Evaluation, Sorting, and Transformation of Data}

The frequency with which each debit category was marked during the 1,301 producer surveys was determined. These data were also sorted according to the MSRO performing the survey $(\mathrm{n}=5 \mathrm{MSRO})$. Because each survey, SCC, and SPC result was linked to a date, the elapsed time between the survey result and each SCC and SPC result ( $\Delta$-time) was calculated for each producer. The distributions of farm size (daily milk production weight), SCC, SPC, and the corresponding log-transformation of these variables were used to identify and eliminate any incorrectly recorded results.

\section{Assessment of Survey Debit Categories for Relationship to SCC and SPC}

An initial literature-based assessment was made to evaluate the possibility of each of the debit categories on the survey form being related to SCC or SPC results (Table 1). In general, deficiencies that increase stress on the cow, decrease the cleanliness of the cow, increase the transfer of mastitis-causing microbes from cow to cow, or are related to incorrect administration of drugs to cattle could be expected to lead to mastitis and high SCC. Deficiencies in several debit categories were assessed as possibly leading to deposition of bacteria on utensils or equipment, or in the milk, or to growth of these bacteria, and thereby an increase in SPC. The results of this assessment were subjectively used in selecting independent variables in the ordinary least squares (OLS) regression equations (described below).

\section{Development of Predictive Equations for SCC and SPC}

The structural set-up for analyzing SCC and SPC levels using regression techniques was developed first. All model pretests were conducted comparatively on the SCC and SPC data and their log-transformed counterparts. The SCC data were continuous, and each value was a measured result. Thus, the SCC and $\ln (\mathrm{SCC})$ models were estimated with OLS regression using the $\mathrm{lm}$ command in R (R-Core Team, 2013). Only SCC results from samples obtained 0 to $14 \mathrm{~d}$ before the date of survey (i.e., $\Delta$-time $\leq 14 \mathrm{~d}$ ) were considered. However, sensitivity analysis suggested that the results were robust with other $\Delta$-time ranges. The SPC data presented different challenges. The actual recorded SPC levels were only reported when the SPC count was above $25,000 \mathrm{cfu} / \mathrm{mL}$. All observations at or below the 25,000 threshold were reported at the threshold. As shown in Table 2, the SPC level at the third quartile remained at $25,000 \mathrm{cfu} / \mathrm{mL}$, which means that less than $25 \%$ of the SPC data were recorded at the actual level of contamination. This finding led to the use of a Tobit regression model, which is the standard approach for analyzing censored data. When properly specified, the Tobit regression is a combination of a truncated regression with all the threshold observations truncated and a univariate probit model with the zero-one distinction at the point of threshold (Greene, 2003). All Tobit regressions were estimated using Stata, version 
Table 1. Debit categories considered in a Wisconsin grade A dairy farm survey

\begin{tabular}{|c|c|c|c|c|c|c|}
\hline \multirow[b]{2}{*}{ General category } & \multicolumn{2}{|c|}{ Description in pasteurized milk ordinance } & \multirow[b]{2}{*}{ Abbreviation } & \multicolumn{2}{|c|}{ Debit linked to } & \multirow[b]{2}{*}{ Pertinent references } \\
\hline & Designation & Name & & $\mathrm{SCC}$ & SPC & \\
\hline Milk & $1 \mathrm{r}$ & Abnormal milk & Cow & $\mathrm{X}$ & & Jones and Bailey, 2009; Ruegg, 2011a \\
\hline \multirow[t]{2}{*}{ Milking barn, stable, or parlor } & $2 \mathrm{r}$ & Construction & $\mathrm{BC}$ & & $\mathrm{X}$ & Pantoja et al., 2009 \\
\hline & $3 \mathrm{r}$ & Cleanliness & $\mathrm{BCl}$ & $\mathrm{X}$ & $\mathrm{X}$ & Oliver, 2010; Ruegg, 2011a \\
\hline Cowyard & $4 \mathrm{r}$ & Cowyard & $\mathrm{CY}$ & $\mathrm{X}$ & $\mathrm{X}$ & $\begin{array}{l}\text { Johnson, 1996; Hayes et al., 2001; Bey et al., } \\
\text { 2002; Ruegg, 2004; Jones and Bailey, 2009; } \\
\text { Oliver, 2010; Mellenberger and Kirk, 2011 }\end{array}$ \\
\hline \multirow[t]{2}{*}{ Milkhouse } & $5 \mathrm{r}$ & Construction and facilities & $\mathrm{MHC}$ & & $\mathrm{X}$ & Oliver, 2010 \\
\hline & $6 \mathrm{r}$ & Cleanliness & $\mathrm{MHCl}$ & & $\mathrm{X}$ & Marth and Steele, 2001 \\
\hline \multirow[t]{2}{*}{ General facilities } & $7 \mathrm{r}$ & Toilet & $\mathrm{T}$ & & $\mathrm{X}$ & \\
\hline & $8 \mathrm{r}$ & Water supply & WST & $\mathrm{X}$ & $\mathrm{X}$ & \\
\hline \multirow{4}{*}{ Utensils and equipment } & $9 \mathrm{r}$ & Construction & UEC & & $\mathrm{X}$ & Dufour et al., 2011 \\
\hline & $10 \mathrm{r}$ & Cleaning & $\mathrm{UECl}$ & & $\mathrm{X}$ & Hayes et al., 2001; Oliver, 2010. \\
\hline & $11 \mathrm{r}$ & Sanitization & UES & & $\mathrm{X}$ & $\begin{array}{l}\text { Elmoslemany et al., 2009; Bava et al., 2010; } \\
\text { Oliver, } 2010\end{array}$ \\
\hline & $12 \mathrm{r}$ & Storage & UESt & & & \\
\hline \multirow[t]{5}{*}{ Conditions during and after milking } & $13 \mathrm{r}$ & Flanks, udders, and teats & FUT & $\mathrm{X}$ & $\mathrm{X}$ & $\begin{array}{l}\text { Johnson, 1996; Barkema et al., 1998; Reneau } \\
\text { et al., 2003; Schreiner and Ruegg, 2003; } \\
\text { Huijps et al., 2009; Dong et al., 2012 }\end{array}$ \\
\hline & $14 \mathrm{r}$ & $\begin{array}{l}\text { Protection from } \\
\text { contamination }\end{array}$ & PfC & & $\mathrm{X}$ & Hayes et al., 2001 \\
\hline & $15 \mathrm{r}$ & Drug and chemical control & DCT & $\mathrm{X}$ & $\mathrm{X}$ & Ruegg and Tabone, 2000 \\
\hline & $18 \mathrm{r}$ & Raw milk cooling & $\mathrm{CT}$ & & $\mathrm{X}$ & Hayes et al., 2001; Marth and Steele, 2001 \\
\hline & $19 \mathrm{r}$ & Insect and rodent control & $\mathrm{PC}$ & & & Jones and Bailey, 2009 \\
\hline \multirow[t]{2}{*}{ Personnel } & $16 \mathrm{r}$ & Handwashing facilities & HWF & $\mathrm{X}$ & $\mathrm{X}$ & Oliver et al., 2005; Jones and Bailey, 2009 \\
\hline & $17 \mathrm{r}$ & Cleanliness & $\mathrm{PeC}$ & & $\mathrm{X}$ & \\
\hline
\end{tabular}


Table 2. Distribution of monthly reported SCC and SPC results and survey data (daily milk production weight, in units of $45.4 \mathrm{~kg}$; and score) for Wisconsin grade A dairy farms January 1 to December 31, 2012

\begin{tabular}{|c|c|c|c|c|}
\hline Item & $\begin{array}{c}\mathrm{SCC} \\
\text { (cells } / \mathrm{mL} \text { ) }\end{array}$ & $\begin{array}{c}\mathrm{SPC} \\
(\mathrm{cfu} / \mathrm{mL})\end{array}$ & $\begin{array}{c}\text { Daily milk } \\
\text { production } \\
\text { weight } \\
\text { (45.4 kg units) }\end{array}$ & $\begin{array}{c}\text { Survey } \\
\text { score } \\
(0-100)\end{array}$ \\
\hline Minimum & 23,000 & $25,000^{2}$ & 1 & 59 \\
\hline 1st quartile & 150,000 & $25,000^{2}$ & 20 & 96 \\
\hline Median & 210,000 & $25,000^{2}$ & 33 & 92 \\
\hline Mean & 244,036 & 32,172 & 81 & 91 \\
\hline 3rd quartile & 309,250 & 25,000 & 65 & 88 \\
\hline Maximum & $1,400,000$ & $2,000,000$ & 2225 & 100 \\
\hline
\end{tabular}

${ }^{1}$ Farms analyzed $(\mathrm{n}=1,301)$ had monthly SCC and SPC results reported for all months in 2012 .

${ }^{2}$ Lower analytical limit of reported SPC results.

12 software (StataCorp, 2011). The specification of the Tobit model (Stata base reference manual, release 12, 2011) was tested at 10,14 , and $24 \mathrm{~d} \Delta$-time intervals using the Cragg/Greene likelihood ratio test. Based on the results, the final model included all observations of reported $\ln (\mathrm{SPC})$ and SPC levels occurring within 24 $\mathrm{d}$ of the survey.

In developing the final models for both the SPC and SCC data, SCC and SPC models made with nontransformed values were compared with their logtransformed counterparts. Analysis of QQ plots of the error terms was done to test the assumption of normality. The predictive equation proposed for SCC yielded a QQ plot, which displayed a nonnormal distribution and a residuals versus fitted plot, which indicated possible incorrect functional form, heteroskedasticity, or both (Figure 1). Log-transformation of the SCC values resulted in no heteroskedasticity in the residuals versus fitted plot (Figure 2). The plots derived from the predictive equation for SPC also displayed possible incorrect functional form, heteroskedasticity, or both (Figure 3). Because functional form issues are commonly associated with heteroskedastic errors (Wooldridge, 2009), log-transformed SCC and SPC data were used in the analysis.

Aside from the survey debit categories, month of the survey, MSRO, and average daily milk production weight were considered for inclusion in both the $\ln (\mathrm{SCC})$ and $\ln (\mathrm{SPC})$ models. The ability of the farm to control SCC and SPC levels reportedly can vary with seasonal temperature and humidity conditions (Dohoo and Meek, 1982; Bewley and Phillips, 2013). High heat and humidity contribute to stress that can reduce bovine immune function (Ontario Ministry of Agriculture and Food, 2013) and support the growth of mastitiscausing pathogenic bacteria (Animal and Plant Health Inspection Service, 1999). Warmer temperatures also favor growth of most mesophilic and pyschrotrophic bacteria, which can contribute to higher SPC results
(Oliver, 2010). These potential seasonal effects suggested that the SCC and SPC models should include dummy variables for each month of the year coinciding with the date of the survey.

In Wisconsin, each MSRO is assigned a geographic territory in which the MSRO is responsible for all farm surveys. Therefore, each MSRO's farms could be unique due to regional topographical and weather differences. A dummy variable for each MSRO-region was included and could be used to provide important information about spatial patterns of SCC and SPC levels in Wisconsin.

Farm size can have an important effect on the overall economics of dairy herd management. For example, large farms may implement production management decisions through a hierarchy of ownership, management, specialists, and general laborers. Small farms may implement decision through a much simpler systems that may only include close family members. The relationship between farm size and SCC or SPC has been an area of past research producing mixed results. As proposed by van Schaik et al. (2002), larger herds can benefit from a dilution effect for managing SCC and SPC: higher counts for subherds that would not pass milk quality standards by themselves are diluted down to acceptable levels by a larger volume of high quality milk from the remainder of the herd. Whereas Norman et al. (2011) and Freije (2012) found that larger herds were generally more likely to have lower SCC values, Dong et al. (2012) found no evidence that herd size affected SCC results when other variables affecting SCC were controlled. In Wisconsin, Ingham et al. (2010) found no evidence for the claim that smaller farms produced higher quality (i.e., lower SCC or lower SPC) milk. Further work in Wisconsin suggested that the amount of milk produced was inversely related to herd SCC and SPC (Borneman and Ingham, 2014). Two variables related to farm size, farm-reported average daily milk production, $\ln (\mathrm{WT})$, and its squared counterpart, $\ln \left(\mathrm{WT}^{2}\right)$, were included to evaluate the hypothesis that health management 


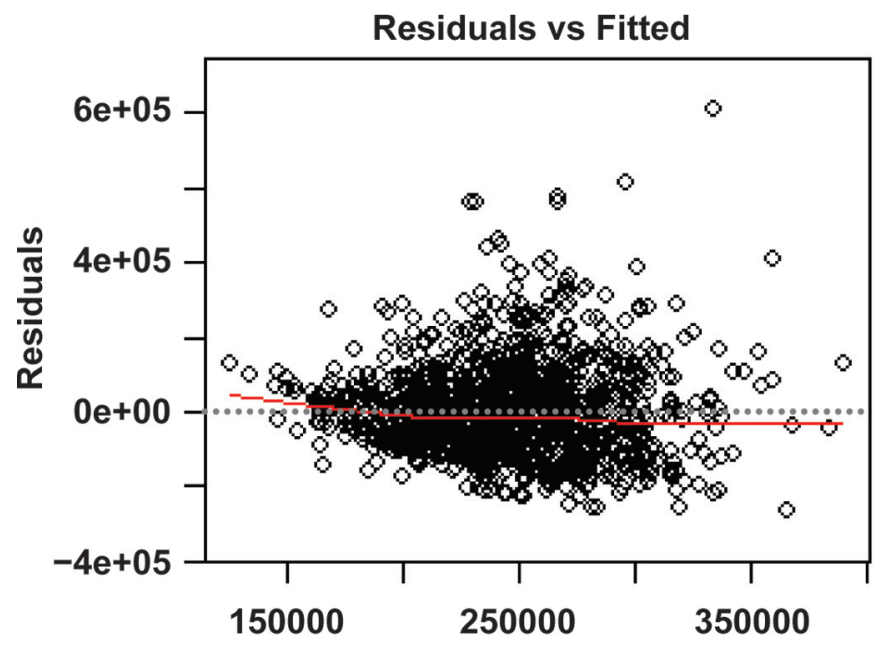

Fitted values

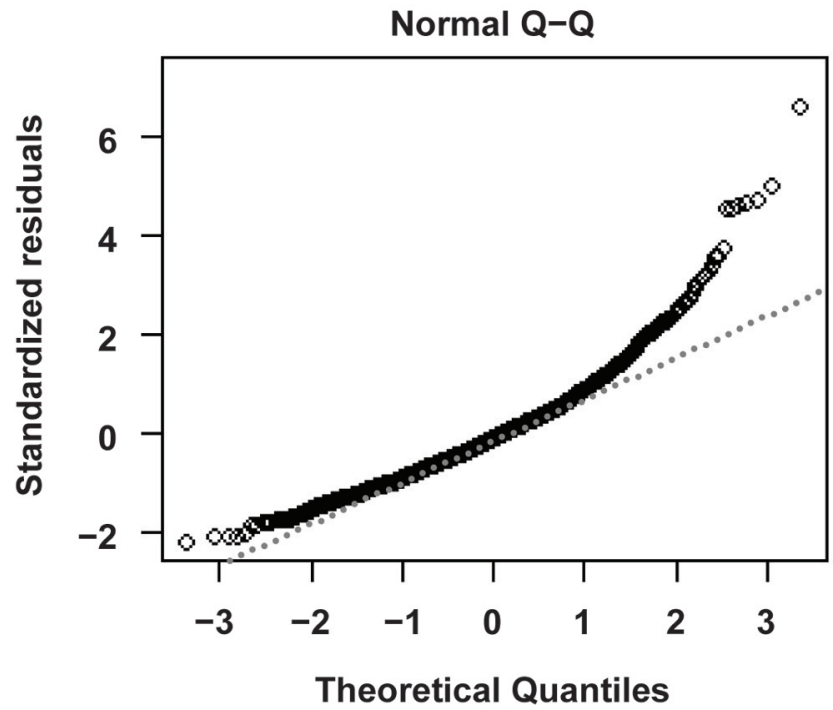

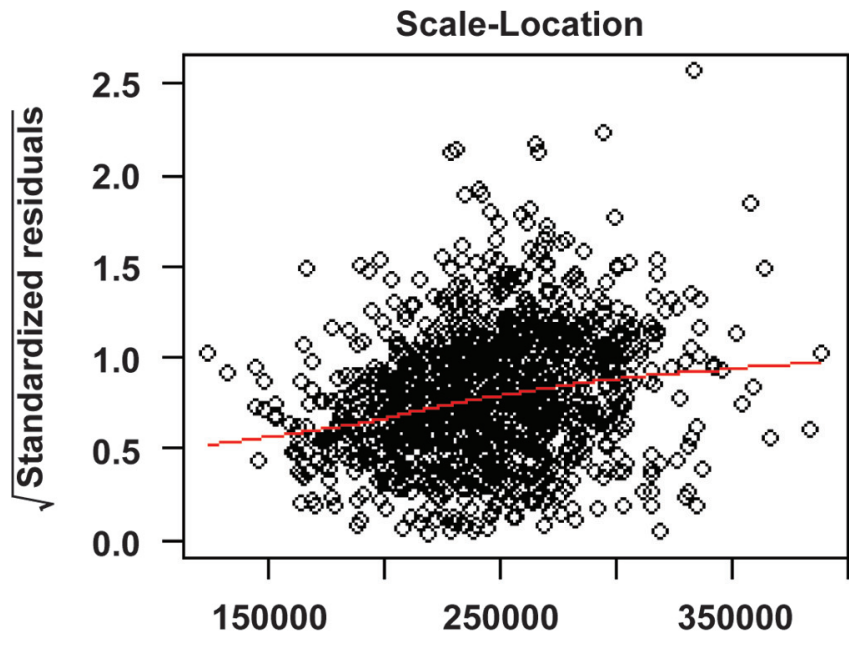

Fitted values

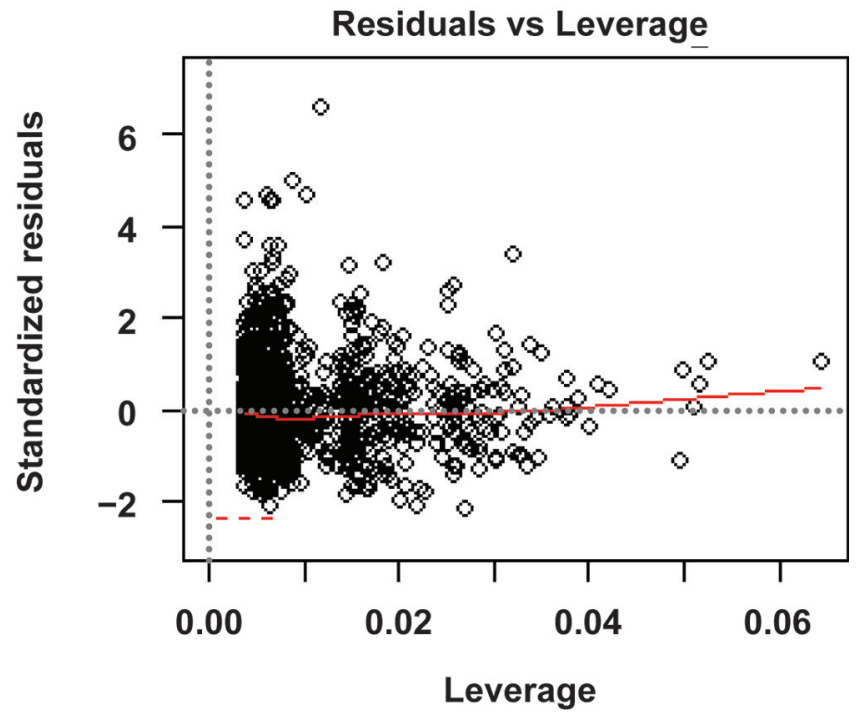

Figure 1. Statistical plots of January 1 to December 31, 2012. Wisconsin grade A dairy farm SCC results reported to Wisconsin Department of Agriculture, Trade and Consumer Protection ( $\mathrm{n}=1,301$ farms). Plots were used to evaluate ordinary least squares model assumptions [residuals vs. fitted and scale-location (heteroskedasticity), normal Q-Q (normality), and residuals vs. leverage (leverage/outliers)]. Plots indicate violations of assumptions of normality and heteroskedasticity. Indicated outlier values were confirmed for accuracy. Color version available online.

systems in different sizes of dairy herds would explain patterns in SCC and SPC.

The initial equations for predicting $\ln (\mathrm{SCC})$, or $\ln (\mathrm{SPC})$, included all available debit categories. Four debits were not observed in the 1,301 Wisconsin grade A dairy farm surveys done in 2012: SCC (cow), personnel cleanliness, bacteria count, and DRA. Subsequent analysis of these regressors, therefore, could not be performed. Table 3 summarizes the total number of debits observed for each item. The adjusted $\mathrm{R}^{2}$ value for the initial regression of $\ln (\mathrm{SCC})$ was evaluated, and all independent regressors were evaluated against an $0.05 \alpha$-level.

\section{SCC Model Pretests and Refinements}

For the model of $\ln (\mathrm{SCC})$, each of the available survey debit regressors and the farm-size regressors in the equations generating the highest adjusted $R^{2}$ values were subsequently evaluated using step-wise regression with the Akaike information criterion (AIC) and the Bayesian information criterion (BIC) to determine if they should remain in the model. The AIC and BIC reward goodness of fit while simultaneously penalizing model overfitting where overfitting refers to inclusion of regressors that are not significant predictors of the dependent variable. The BIC uses a larger penalty than 

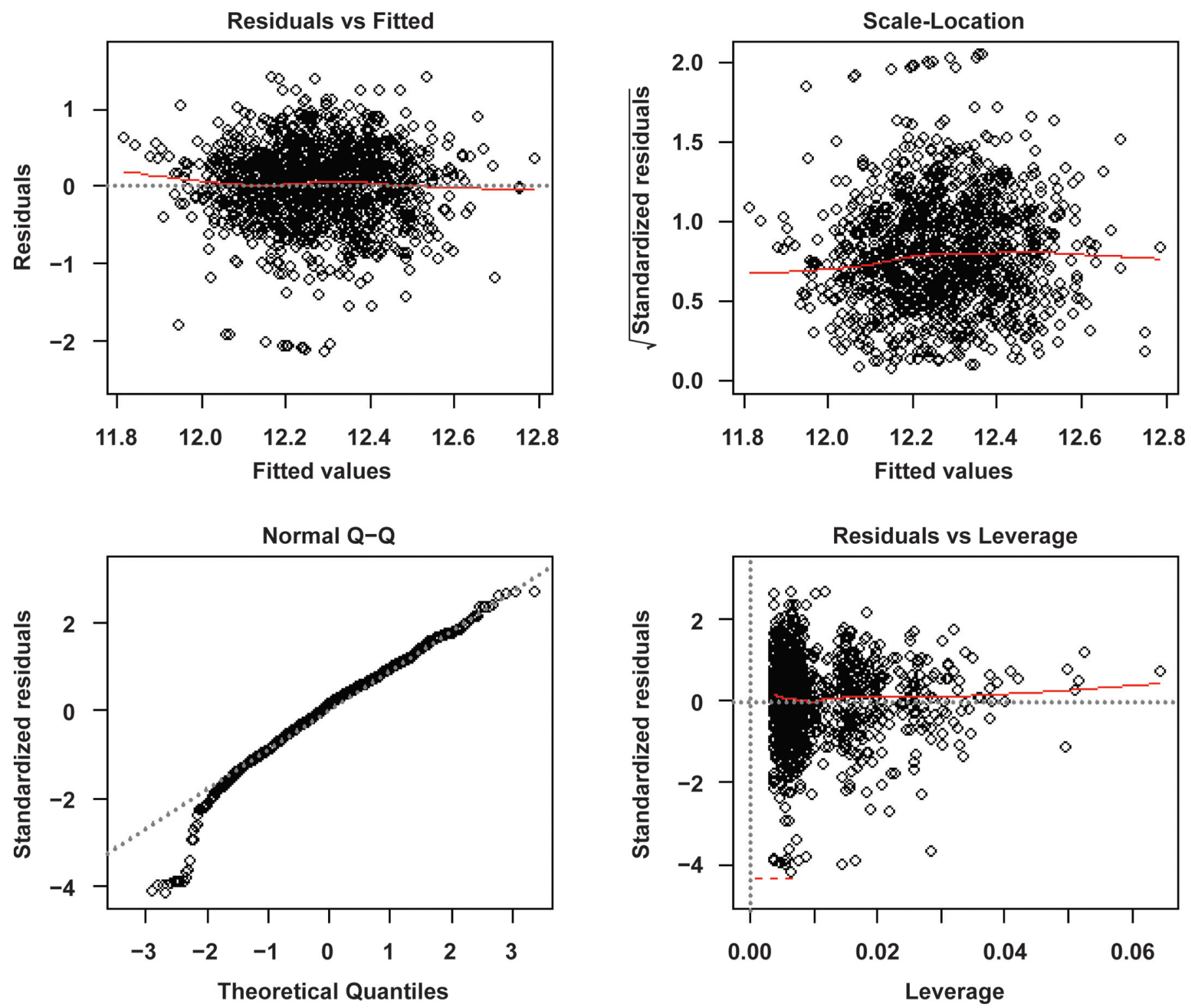

Figure 2. Statistical plots of ln-transformations of Wisconsin grade A dairy farm SCC results reported to the Wisconsin Department of Agriculture, Trade and Consumer Protection January 1 to December 31, 2012 ( $\mathrm{n}=1,301$ farms). Plots were used to evaluate ordinary least squares model assumptions [residuals vs. fitted and scale-location (heteroskedasticity), normal Q-Q (normality), and residuals vs. leverage (leverage/outliers)]. Plots indicate no violations of the assumptions of nonconstant variance in residuals (heteroskedasticity). Issues with normality are adequately addressed by the central limit theorem. Color version available online.

AIC (i.e., has a higher threshold) in determination of whether a potential variable should be retained or dropped.

\section{Predicting SCC: Marginal Effects Analysis and Final Model}

Interaction terms were also considered as a method of attempting to reduce the error variance of the model for predicting $\ln (\mathrm{SCC})$. The marginal effects of interaction were considered because previous research suggested that the dependent variable, $\ln (\mathrm{SCC})$, may be partly related to not only an independent variable, but also to the magnitude of another independent variable; that is the partial effect of one independent variable is dependent upon the value of a different explanatory variable (Wooldridge, 2009). For final model preparation, all variables, interactions, and quadratic terms deemed to be statistically insignificant based on literature review, well-understood biological principles, or AIC analysis were removed from the final regression model. The final regression equation was 


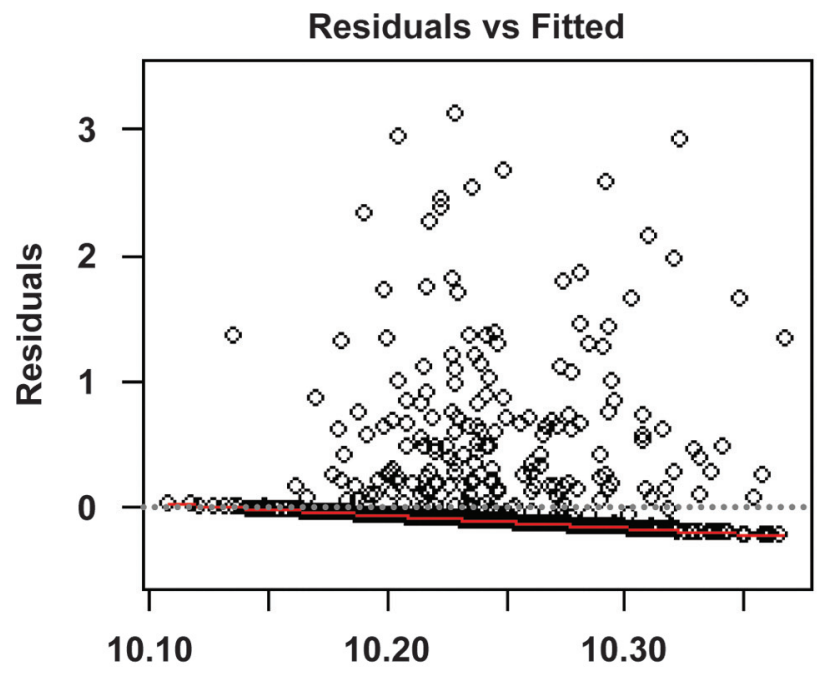

Fitted values

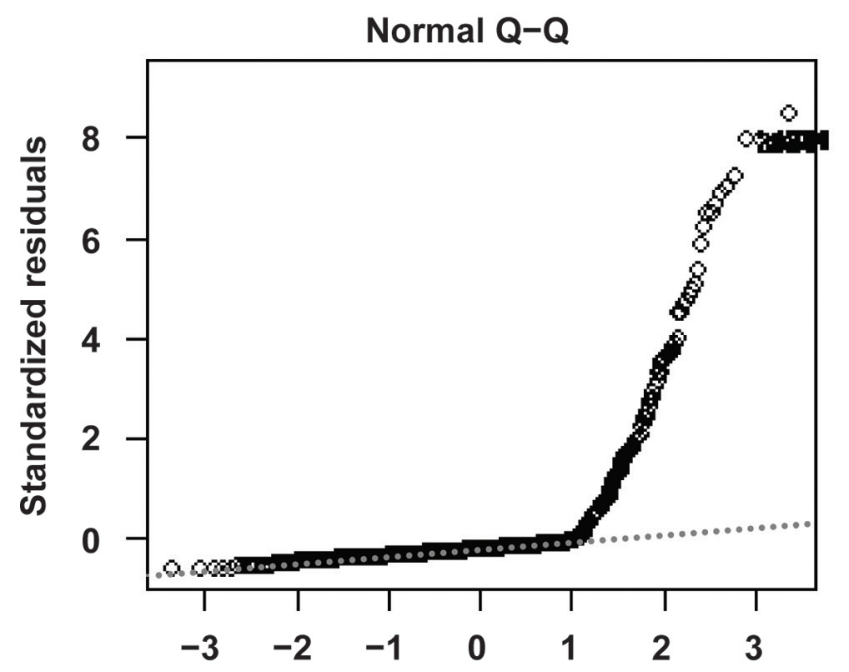

Theoretical Quantiles
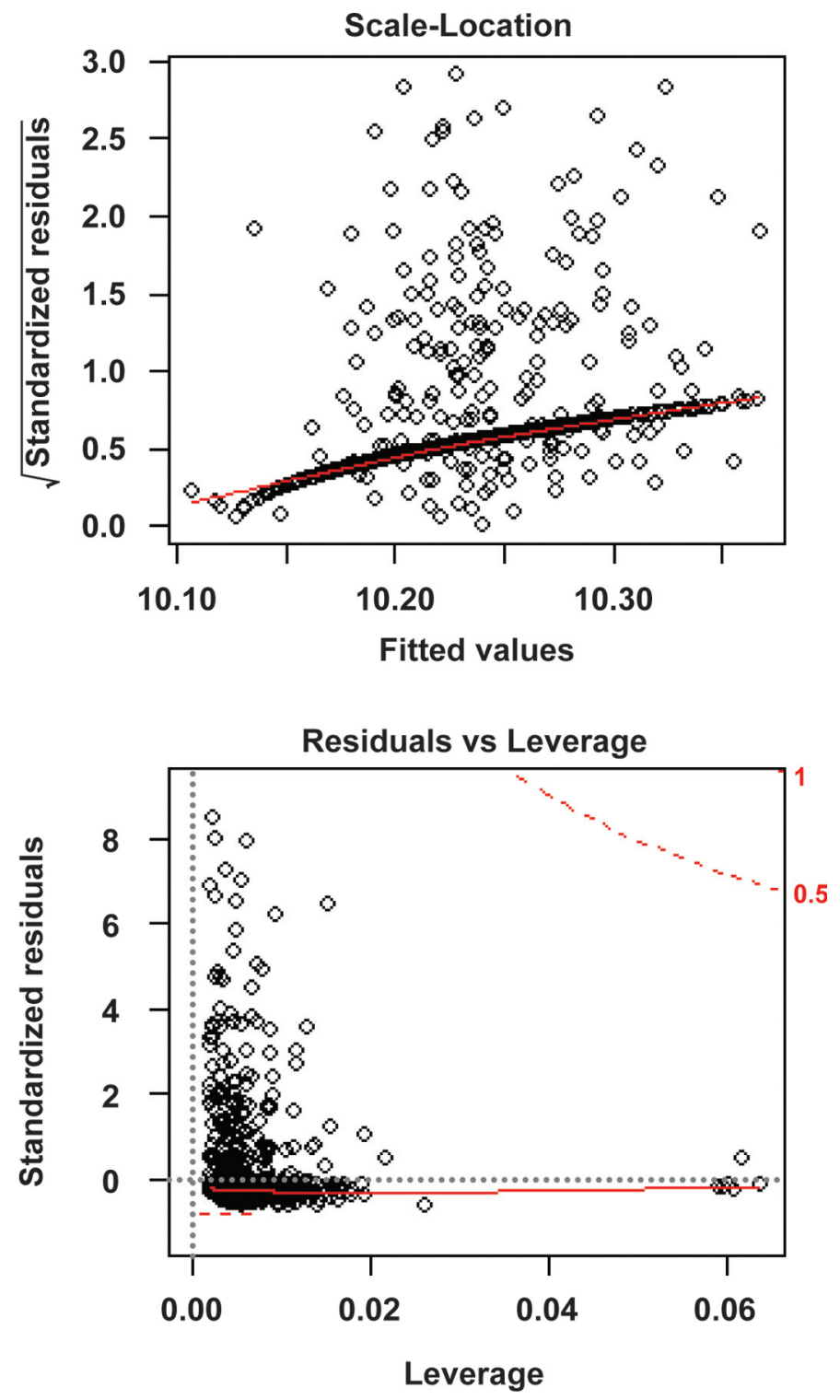

Figure 3. Statistical plots of ln-transformations of Wisconsin grade A dairy farm Standard Plate Count results $(\mathrm{n}=1,301$ farms) reported to the Wisconsin Department of Agriculture, Trade and Consumer Protection January 1 to December 31, 2012. Plots were used to evaluate ordinary least squares model assumptions [residuals vs. fitted and scale-location (heteroskedasticity), normal Q-Q (normality), and residuals vs. leverage (leverage/outliers)]. Plots indicate no violations of the assumptions of nonconstant variance in residuals (heteroskedasticity). Issues with normality are adequately addressed by the central limit theorem. Color version available online.

$$
\begin{aligned}
\ln (S C C)= & b_{0}+\sum_{i=1}^{4} b_{i} M S R O_{i}+\sum_{m=1}^{11} b_{m+5} S D N_{m}+ \\
& b_{17} \ln (W T)+b_{18} B C l+b_{19} M H C+ \\
& b_{20} U E S+b_{21} B C+b_{22} M H C l+e .
\end{aligned}
$$

This model included 22 parameters, with 4 parameters associated with the MSRO spatial dummy variables, 11 monthly seasonal dummy variables, average daily milk production; milking barn-, stable-, or parlor-cleanliness (BCl); milkhouse construction (MHC), utensil and equipment sanitation (UES); milking barn-, stable-, or parlor-construction (BC), and milkhouse cleanliness (MHCl).

After reducing the number of explanatory variables [1] as already described, the sensitivity of the revised equation was re-evaluated for differing $\Delta$-time values. The 14-d model $(\Delta$-time $\leq 14 \mathrm{~d})$ for $\ln (\mathrm{SCC})$ and the 24 -d model $(\Delta$-time $\leq 24 \mathrm{~d})$ for $\ln (\mathrm{SPC})$ were determined to be reasonable. 


\section{RESULTS AND DISCUSSION}

\section{Predicting SCC Results: Testing of Initial OLS Regression Equations}

The initial OLS regression equation for $\ln (\mathrm{SCC})$ had an adjusted $R^{2}$ value of 0.047 , indicating that the selected variables were explaining less than $5 \%$ of the variance observed in SCC. All independent regressors, with the exception of drug and chemical control $(P=$ $0.054)$, were highly statistically significant at the 0.05 $\alpha$-level. Significance in this case refers to the likelihood that the observed difference in $\ln (\mathrm{SCC})$ associated with an independent regressor is not due to random chance. The effects of seasonality were significant for several months, but the expected correlation of season and $\ln (\mathrm{SCC})$ was not always observed. The daily milk production weight was highly significant and negative as a predictor of $\ln (\mathrm{SCC})$ levels $\left(P \leq 2 \times 10^{-16}\right)$. This finding indicates that not only is production weight a potentially very good predictor of SCC, it is inversely related, indicating that larger farms are more likely to have lower SCC results. This association may be related, at least in part, to the dilution effect previously discussed, but may also be indicative that, in general, larger farms are more likely to implement practices that result in lower SCC.

\section{Model Refinements}

The AIC based step-wise regression retained month and MSRO dummy variables, $\ln (\mathrm{WT}), \ln \left(\mathrm{WT}^{2}\right), \mathrm{BCl}$, water supply (WST), MHC, UES, BC, and $\mathrm{MHCl}$. Cow, cowyard (CY), flanks, udders, and teats (FUT), drug and chemical control, and insect and rodent control (PC) were dropped as regressors from the model. Overall, the regressors in the new equation explained about $8 \%$ of the total observed variation in $\ln (\mathrm{SCC})$ (adjusted $\mathrm{R}^{2}=0.079$ ).

The recommendation for the inclusion of MHC, UES, $\mathrm{BC}$, and $\mathrm{MHCl}$ do merit consideration. Only $\mathrm{MHC}$ was significant at $\alpha$-level $0.05(P=0.022)$. Dufour et al. (2011) noted that the condition and age of milking equipment, housing, and manure management machinery/practices are associated with SCC levels, which may indicate that BC should be included. Ruegg (2004, 2011b) noted that an infected cow can infect otherwise healthy cows (contagious mastitis) through milk droplets on milking liners, shared towels, contaminated hands of a milking technician, or bedding surfaces. This finding may warrant the consideration and inclusion of UES in future models as well. For models utilizing different data sets, the value of these regressors should be tested to prevent omitted variable bias.
A step-wise regression utilizing the BIC was also used to test the relative quality of each identified independent variable. This testing identified the daily milk production weight and $\mathrm{BCl}$ as the best predictors of $\ln (\mathrm{SCC})$. It was expected that the BIC step routine may suggest fewer regressors than the AIC because BIC operates with a larger penalty term for the number of parameters in the model. Utilization of daily milk production weight and $\mathrm{BCl}$ accounted for about $4.5 \%$ of the predictive power of $\ln (\mathrm{SCC})$ based on the adjusted $\mathrm{R}$-squared value of the model. This model is likely to both be too simplistic and have omitted variable bias if used on other data sets.

\section{Predicting SCC: Marginal Effects Analysis and Final Model}

Interaction terms considered for prediction of SCC were UECl_UES and UECl_UESt. Proper cleaning, sanitizing, and storage of milking equipment have been shown to be highly important influences on bacterial counts. Of the interaction terms tested, neither was deemed statistically significant (UECl_UES, $P=$ 0.9417 , and UECL_UESt, $P=0.5891)$. The quadratic curvilinear regression term $\ln \left(\mathrm{WT}^{2}\right)$ was also determined to be marginally insignificant and dropped from the predictive equation.

Some interesting and potentially useful findings were related to the individual regression parameters. Three of the 4 MSRO spatial dummies were found to be positive and statistically different than region 3 . This means that regions 1,4 , and 5 all had average $\ln (\mathrm{SCC})$ levels above that of region 3 and that region 3 was the strongest performing region in the state. We also found higher $(P \leq 0.001)$ average SCC counts in all months relative to December. This is consistent with previous studies suggesting that lower SCC counts are typically observed in cooler months.

After controlling for seasonality and MSRO/region, many of the variables associated with the survey suggested statistical causality in $\ln (\mathrm{SCC})$ variation. Importantly, the variable of daily milk production weight $\ln (\mathrm{WT})$ was highly statistically significant and negative, meaning that SCC and farm size (weight of milk output) are inversely related [i.e., as weight increases, $\ln$ (SCC) decreases]. Because both the dependent variable and the WT are log-transformed, the coefficient is interpreted as an elasticity. Its value $(-0.0763)$ means that a $10 \%$ increase in farm size leads to a $0.7 \%$ reduction in average SCC levels. This may have important policy ramifications for small milk producers because they will be less likely to consistently meet more stringent SCC requirements. This conclusion supports previously published work in which authors noted that in 
Table 3. Summary of debit category observations (potential regressors) noted during 2012 surveys of Wisconsin grade A dairy farms

\begin{tabular}{llr}
\hline $\begin{array}{l}\text { Debit category } \\
\text { abbreviation }\end{array}$ & Debit category title & Observations $^{1}$ \\
\hline Cow & Abnormal milk & 69 \\
BC & Milking barn, stable, or parlor - construction & 248 \\
BCl & Milking barn, stable, or parlor - cleanliness & 438 \\
CY & Cowyard & 53 \\
MHC & Milkhouse construction and facilities & 845 \\
MHCl & Milkhouse-cleanliness & 291 \\
T & Toilet & 34 \\
WST & Water supply & 271 \\
UEC & Utensils and equipment-construction & 209 \\
UECl & Utensils and equipment-cleaning & 238 \\
UES & Utensils and equipment-sanitization & 218 \\
UESt & Utensils and equipment-storage & 300 \\
FUT & Milking-flanks, udders, and teats & 98 \\
PfC & Protection from contamination & 247 \\
DCT & Drug and chemical control & 179 \\
HWF & Personnel-handwashing facilities & 72 \\
PeC & Personnel-cleanliness & 0 \\
CT & Raw milk cooling & 23 \\
PC & Insect and rodent control & 377 \\
BAC & Bacteria count & 0 \\
DRA & Drug residue analysis & 0 \\
SDN & Sample date of laboratory testing & N/A \\
\hline${ }^{1}$ Observations indicates the total number of times surveyed Wisconsin dairy farms (n= 1,301) were cited for \\
a debit in the designated category.
\end{tabular}

general larger farms produce lower SCC milk (Norman et al., 2011; Freije, 2012; Borneman and Ingham, 2014).

The results for the estimation of equation [1] using $\ln (\mathrm{SCC})$ data from a $\Delta$-time $\leq 14 \mathrm{~d}$ window $(\mathrm{n}=717)$ are presented in Table 4 . The adjusted $\mathrm{R}^{2}$ value of 0.143 , although obtained with a sufficiently large sample size, is not large, perhaps indicating that survey debits cannot predict SCC as a measure of milk quality with a high degree of accuracy. Importantly, SCC levels are recorded from 0 to $14 \mathrm{~d}$ in advance of the survey date. Thus, SCC results temporally farther away from the survey may reflect farm conditions that differ from those during the survey, thereby introducing unexplained and random variance into the estimation. Furthermore, visual evaluations of hygiene can fail to detect contamination with pathogenic bacteria that cause or prolong mastitis in a dairy herd. Finally, a survey may not coincide with, or an MSRO may not observe, unsound employee practices that could lead to high SCC.

Equation [1] contained the regressors $\mathrm{BCl}, \mathrm{MHC}$, and UES, which remained significant at an $\alpha$-level of 0.05 (Table 4). The estimates of these significant regressors were all positive, indicating that they were positively correlated with $\ln (\mathrm{SCC})$; that is, observation of these debits likely resulted in an elevated SCC value. The other 3 independent debit-based variables, WST, BC, and $\mathrm{MHCl}$, were not significant.

Even though it was not considered significant for this data set, elimination of abnormal milk (cow) is likely to result in omitted variable bias because most incidences of abnormal milk are intuitively expected to be associated with mastitis, and SCC reportedly is a very good indicator of mastitis (Nielsen et al., 2010). The elimination of CY and FUT could be inappropriate, dependent upon which postmilking procedures (e.g., teat dipping) are followed, how soon after milking recontamination occurs (especially to the teat ends), and which types of udder/teat preparation were used on the subsequent milking. Strong evidence exists in the scientific literature suggesting that these 2 factors have a significant effect on SCC; therefore, elimination would not be advised without testing on other data sets. The debit category drug and chemical control covers some activities having potentially strong ties to SCC; for example, drug misuse, and others potentially tied to high SPC, such as improper sanitizer use. Because the survey form does not allow separation of these 2 factors, prediction based on this variable is difficult. The loss of PC was not surprising because the effect of pest control practices on SCC would mostly likely be indirect, but the scientific literature has shown a causal link. Again, elimination should be considered carefully because it may cause omitted variable bias in future models using a different data set.

\section{Predicting SPC}

The procedures for reducing the $\ln (\mathrm{SPC})$ Tobit model were similar to those done with the $\ln (\mathrm{SCC})$ OLS model. When the specification of the Tobit model 
Table 4. Ordinary least squares (OLS) regression estimates of effects of variables on producer milk $\ln (\mathrm{SCC})$ levels utilizing survey results for producers with SCC results reported not more than $14 \mathrm{~d}$ before survey; $\mathrm{n}=$ 717 farms $)^{1,2}$

\begin{tabular}{lccrc}
\hline Coefficient & Estimate & $\mathrm{SE}$ & $\mathrm{t}$-value & $P(>|\mathrm{t}|)$ \\
\hline (Intercept) & 11.31254 & 0.2180959 & 51.87 & 0.000 \\
MSRO1 & 0.2089882 & 0.0806703 & 2.59 & 0.010 \\
MSRO2 & 0.1308898 & 0.0817423 & 1.60 & 0.110 \\
MSRO4 & 0.1976566 & 0.0841558 & 2.35 & 0.019 \\
MSRO5 & 0.2932203 & 0.0854796 & 3.43 & 0.001 \\
SDN1 & 0.8975853 & 0.2230143 & 4.02 & 0.000 \\
SDN2 & 0.9834067 & 0.2206667 & 4.46 & 0.000 \\
SDN3 & 0.8829412 & 0.2248447 & 3.93 & 0.000 \\
SDN4 & 1.022922 & 0.2234528 & 4.58 & 0.000 \\
SDN5 & 0.8878412 & 0.2127721 & 4.17 & 0.000 \\
SDN6 & 0.9117065 & 0.2141578 & 4.26 & 0.000 \\
SDN7 & 0.9017793 & 0.2200375 & 4.10 & 0.000 \\
SDN8 & 1.204805 & 0.2184975 & 5.51 & 0.000 \\
SDN9 & 0.9932242 & 0.2178164 & 4.56 & 0.000 \\
SDN10 & 0.2215226 & 3.66 & 0.000 \\
SDN11 & 0.8116924 & 0.2324793 & 4.08 & 0.023 \\
ln(WT) & 0.9494417 & 0.019397 & -3.94 & 0.733 \\
BCl & -0.076371 & 0.0151594 & 2.27 & 0.016 \\
WST & 0.0344176 & 0.0121046 & -0.34 & 0.025 \\
MHC & -0.004132 & 0.0175468 & 2.43 & 0.723 \\
UES & 0.0425643 & 0.0114229 & 2.25 & 0.183 \\
BC & 0.0256447 & 0.0499347 & 0.35 & 1.33 \\
MHCl & 0.0176948 & 0.0133445 & & 0.000 \\
\hline
\end{tabular}

${ }^{1}$ SCC OLS model: $\ln (\mathrm{SCC}) \sim \mathrm{MSRO}+\ln (\mathrm{WT})+\mathrm{SDN}+\mathrm{BCl}+\mathrm{MHC}+\mathrm{UES}+\mathrm{BC}+\mathrm{MHCl}$. Coefficient $\mathrm{MSRO}=$ milk sanitation rating officer; coefficient SDN = month in which survey was conducted; coefficient $\ln (\mathrm{WT})=\log$ of daily milk production weight; other coefficients represent debit category titles as defined in Table 3.

${ }^{2}$ Residual standard error $=0.2755$ on 694 df. Multiple $\mathrm{R}^{2}=0.1695$, adjusted $\mathrm{R}^{2}=0.1432 . \quad F$-statistic $=6.44$ on 22 and $694 \mathrm{df}, P$-value $=0.0000$.

was tested with 10,14 , and $24 \mathrm{~d} \Delta$-time intervals using the Cragg/Greene likelihood ratio test, only the 24-d interval passed. The final model thus included all observations of reported $\ln (\mathrm{SPC})$ and SPC levels occurring within $24 \mathrm{~d}$ of the survey. This left 104 of the 1,136 observations in the Tobit regression uncensored: $90 \%$ of the observations were at the 25,000 threshold. The large percentage of observations at the threshold does not pose a problem in Tobit regression and having over 100 observations above the threshold is a sufficient number to conduct the analysis.

Across the range of different specifications, a consistently poor fit was found. In addition, the MSRO and seasonality dummy variables were not individually significant. Joint $\chi^{2}$ tests of the MSRO group of variables and seasonality group of variables suggested they did not provide any information about SPC variation. The only debit variable that showed statistical significance was $\mathrm{BCl}$.

Several factors may explain such poor performance of the Tobit regression. First, whereas expanding the $\Delta$-time interval to $24 \mathrm{~d}$ increased the number of uncensored observations and met the Cragg/Greene diagnostic, it also increased the time during which farm operators could have altered their practices after being informed of a high SPC result (an uncensored observa- tion) and before the survey. Such a change in practices could affect the audit results. Second, the debit survey may be a poor predictor of SPC levels because bacterial growth in hygienically collected milk can result from poor refrigeration, which is only reflected in one of the 19 possible survey debit categories. Poor refrigeration leading to bacterial growth could obscure the effect on SPC of sanitation practices or conditions linked to other survey debit categories. The SCC level does not change with temperature abuse, so any effects on SCC related to hygienic conditions (and associated debit categories) would not be obscured, thus making accurate prediction based on survey debits more likely for SCC than SPC. Third, the auditing procedure assigns debits only when the violation is observed. Thus, absence of a debit may mean inadequate practices or that no observation was made. Debits related to milking operation, the part most closely associated with SPC, might not be assigned if milking is not being done during the survey. And finally, the 25,000 threshold is likely to be too high to include farms that target specific markets or have contracts which specify much lower levels.

Several of the above factors suggest that changes in the survey should be considered. Changes could include scheduling surveys only during times of active milking or allowing a not observed response for debits, rather 
than only a marked or not marked response, and taking concurrent milk samples for SCC and SPC analyses.

\section{CONCLUSIONS}

From this study, it can be concluded that either weak, or strong but yet undiscovered, relationships are present between on-site survey debits and SCC or SPC. Further studies could examine individual debits, rather than debit categories, as the independent regressors of SCC or SPC, or more thoroughly consider the importance of interaction terms, involving multiple debits or debit categories, as possible regressors of SCC and SPC. Such analyses would necessitate a considerably larger data set than used in this study. Synchronizing sample collection for SCC and SPC analyses with the survey might enhance detection of important relationships that are otherwise missed because of the time gap between survey and sampling. This possibility warrants further study. Alternatively, it could be argued that the debits that might be marked in the on-site survey should be dramatically revised. Considerable research effort would be necessary to determine what new potential debit(s) would be related most closely with SCC and SPC. If such debits were identified, the process of changing the PMO and state regulations to mandate use of these debits would take many years of effort. It also could be argued that the current survey debits are appropriate and objective measurements other than, or along with, SCC or SPC should be used to measure milk hygienic quality. Identification of new objective quality measures, and adoption of these measures by regulators, would also take many years.

\section{ACKNOWLEDGMENTS}

The authors thank the staff in the Eau Claire office of the Wisconsin Department of Agriculture, Trade and Consumer Protection, Division of Food Safety, for obtaining and organizing the data for our analysis. The authors gratefully acknowledge Cécile Ané, Department of Statistics, University of Wisconsin-Madison, for her assistance with the statistical analysis and interpretation of results for this research. The authors recognize Lead MSRO Robert Klika and MSRO Brian Jindra, who provided valuable insight into the survey process and allowed accompaniment to observe the state rating process on site at a number of Wisconsin dairy farms.

\section{REFERENCES}

Animal and Plant Health Inspection Service (APHIS). 1999. Monitoring U.S. milk quality using bulk tank somatic cell counts, 1997. Info sheet. Accessed Jan. 4, 2013. http://www.aphis.usda. gov/animal_health/nahms/dairy/downloads/dairy_monitoring/ BTSCC 97infosheet.pdf.

Barkema, H., Y. Schukken, T. Lam, H. Beoboer, G. Benedictus, and A. Brand. 1998. Management practices associated with low, medium, and high somatic cell counts in bulk milk. J. Dairy Sci. 81:1917-1927.

Bava, L., M. Zucali, M. Brasca, L. Zanini, and A. Sandrucci. 2010. Efficiency of cleaning procedure of milking equipment and bacterial quality of milk. Ital. J. Anim. Sci. 8:387-389.

Bewley, J., and D. Phillips. 2013. Using DHIA Records for Somatic Cell Count Management. Accessed Nov. 15, 2013. http://www2. ca.uky.edu/agc/pubs/ID/ID212/ID212.pdf.

Bey, R., J. Reneau, and R. Farnsworth. 2002. The role of bedding management in udder health. Proc. Natl. Mastitis Council 41:45-55.

Borneman, D. L., and S. Ingham. 2014. Evaluating Wisconsin dairy producer compliance and potential eligibility for international markets under existing European Union and United States grade "A" bulk tank somatic cell count compliance criteria. Food Policy 46:150-156.

Chambers, J. 2002. Dairy Microbiology Handbook. 3rd ed. R. Robinson, ed. John Wiley and Sons Inc., New York, NY.

Dohoo, I., and A. Meek. 1982. Somatic cell counts in bovine milk. Can. Vet. J. 23:119-125.

Dong, F., A. Hennessy, and H. Jensen. 2012. Factors determining milk quality and implications for production structure under somatic cell count standard modification. J. Dairy Sci. 95:6421-6435.

Dufour, S., A. Fréchette, H. Barkema, A. Mussell, and D. Scholl. 2011. Invited review: Effect of udder health management practices on herd somatic cell count. J. Dairy Sci. 94:563-579.

Elmoslemany, A., G. Keefe, I. Dohoo, and B. Jayarao. 2009. Risk factors for bacteriological quality of bulk tank milk in Prince Edward Island dairy herds. Part 2: Bacteria count-specific risk factors. J. Dairy Sci. 92:2644-2652.

Freije, C. 2012. Analysis of component levels and somatic cell count in individual herd milk at the farm level 2010. Accessed Jan. 18, 2012. http://www.fmma30.com/StaffPapers/StaffPaper12-02.pdf.

Greene, W. H. 2003. Econometric Analysis. 5th ed. Prentice Hall, Upper Saddle River, NJ.

Hayes, M., R. Ralyea, S. Murphy, N. Carey, J. Scarlett, and J. Boor. 2001. Identification and characterization of elevated microbial counts in bulk tank raw milk. J. Dairy Sci. 84:292-298.

Huijps, K., T. Lam, H. Hogeveen, G. Antonides, N. Valeeva, G. Alfons, O. Lansink, and R. Huirne. 2009. Economic decisions in mastitis management. Accessed Mar. 1, 2013. http://igitur-archive.library. uu.nl/dissertations/2009-1104-200137/UUindex.html.

Hutchison, M., D. Thomas, A. Moore, D. Jackson, and I. Ohnstad. 2005. An evaluation of raw milk microorganisms as markers of onfarm hygiene practices related to milking. J. Food Prot. 68:764772 .

Ingham, S., W. VanHove, R. Jeutong, C. Adamson, R. Battaglia, and T. Leitzke. 2010. Correlation of on-site inspection and laboratory milk testing results for Wisconsin grade A dairy farms in 2007 and 2008. J. Dairy Sci. 93:3957-3960.

Jayarao, B., and D. Wolfgang. 2003. Bulk-tank milk analysis-A useful tool for improving milk quality and herd udder health. Vet. Clin. North Am. Food Anim. Pract. 19:75-92.

Johnson, A. 1996. Quality milk production: Milking practices and procedures. Accessed Oct. 15, 2013. http://www.wcds.ca/proc/1996/ wcd96349.htm.

Jones, G., and T. Bailey. 2009. Virginia Cooperative Extension. Understanding the basics of mastits. Accessed Oct. 1, 2013. http:// en.engormix.com/MA-dairy-cattle/health/articles/understandingbasics-mastitis-t1324/p0.htm.

Kelly, P., K. O'Sullivan, D. Berry, S. More, W. Meaney, E. O'Callaghan, and B. O'Brien. 2009. Farm management factors associated with bulk tank total bacterial count in Irish dairy herds during 2006/07. Ir. Vet. J. 62:36-42.

Marth, E., and J. Steele. 2001. Applied Dairy Microbiology. CRC, New York, NY.

Mellenberger, R., and J. Kirk. 2011. Mastitis control program for coliform mastitis in dairy cows. Accessed Oct. 15, 2013. http://milk 
quality.wisc.edu/wp-content/uploads/2011/09/mastitis-controlprogram_coliform-mastitis.pdf.

Nielsen, C., S. Ostergaard, U. Emanuelson, H. Andersson, B. Berglund, and E. Strandberg. 2010. Economic consequences of mastitis and withdrawal of milk with high somatic cell count in Swedish dairy herds. Animal 4:1758-1770.

Norman, H., J. Lombard, J. Wright, C. Kopral, J. Rodriquez, and R. Miller. 2011. Consequence of alternative standards for bulk tank somatic cell count of dairy herds in the US. J. Dairy Sci. 94:6243-6256.

Oliver, S. 2010. How milk quality is assessed. Dairy. Accessed Jan. 7 , 2013. http://www.extension.org/pages/21197/how-milk-qualityis-assessed.

Oliver, S., B. Jayarao, and R. Almeida. 2005. Foodborne pathogens, mastitis, milk quality, and dairy food safety. Accessed Aug. 28, 2013. http://nmconline.org/articles/MilkQualFoodSafety.pdf.

Ontario Ministry of Agriculture and Food. 2013. Keep your dry cows cool for optimum milk production. Accessed Jan. 2, 2013. http:// www.omaf.gov.on.ca/english/livestock/dairy/facts/drycowcool.htm.

Pantoja, J., D. Reinemann, and P. Ruegg. 2009. Associations among milk quality indicators in raw bulk milk. J. Dairy Sci. 92:49784987.

Peeler, J., J. Messer, R. Sanders, and H. Bachelor. 1989. A comparison of preliminary incubation counts and standard plate counts of grade A bulk tank milk from eleven states. Dairy Food and Env. San. 9:494-497.

R Core Team. 2013. R: A language and environment for statistical computing. R Foundation for Statistical Computing, Vienna, Austria. http://www.R-project.org.

Reneau, J., A. Saylor, B. Heinz, R. Bye, and R. Farnsworth. 2003. Relationship of cow hygiene scores and SCC. Proceedings of the National Mastitis Council 42:362-363.

Ruegg, P. 2004. Managing for milk quality. Accessed Oct. 3, 2013. http:// milkquality.wisc.edu/wp-content/uploads/2011/09/managing-formilk-quality_english.pdf.

Ruegg, P. 2011a. Heifer mastitis: how to help heifers calve clean. Accessed Oct. 3, 2013. http://milkquality.wisc.edu/wp-content/ uploads/2011/09/Heifer-Mastitis-Conference.doc.
Ruegg, P. 2011b. Premiums, production, and pails of discarded milk how much money does mastitis cost you? Accessed Oct. 3, 2013. http:// milkquality.wisc.edu/wp-content/uploads/2011/09/how-muchmoney-does-mastitis-cost.pdf.

Ruegg, P., and T. Tabone. 2000. The relationship between antibiotic residue violations and somatic cell counts in Wisconsin dairy herds. J. Dairy Sci. 83:2805-2809.

Schreiner, D., and P. Ruegg. 2003. Relationship between udder and leg hygiene scores and subclinical mastitis. J. Dairy Sci. 86:34603465

StataCorp. 2011. Stata: Release 12. Statistical Software. College Station, TX.

US Department of Health and Human Services. 2009. Methods of making sanitation ratings of milk shippers. Accessed Jan. 2, 2014. http://www.fda.gov/downloads/Food/FoodSafety/ProductSpecificInformation/MilkSafety/NationalConferenceonInterstate MilkShipmentsNCIMSModelDocuments/UCM199077.pdf.

US Department of Health and Human Services. 2011. Grade "A" pasteurized milk ordinance, 2011 Revision. Accessed Mar. 13, 2013. http://www.fda.gov/downloads/Food/FoodSafety/ProductSpecificInformation/MilkSafety/NationalConferenceonInterstate MilkShipmentsNCIMSModelDocuments/UCM209789.pdf.

US FDA. 2013. M-I-05-3: Updated official laboratory evaluation forms (FDA-2400 series). Accessed Nov. 18, 2014. http://www.fda. gov/Food/GuidanceRegulation/GuidanceDocumentsRegulatory Information/Milk/ucm075155.htm.

van Schaik, G., M. Lotem, and Y. Schukken. 2002. Trends in somatic cell counts, bacterial counts, and antibiotic residue in New York State during 1999-2000. J. Dairy Sci. 85:782-789.

Wisconsin Administrative Code. 2013. Chapter ATCP 60 Dairy Farms. Accessed Mar. 13, 2013. http://docs.legis.wisconsin.gov/ code/admin_code/atcp/60.pdf.

Wooldridge, J. 2009. Introductory Econometrics: A Modern Approach. 4th ed. South-Western-Cengage Learning, Mason, OH. 